\title{
Crop Injury from Sublethal Rates of Herbicide. II. Cucumber
}

\author{
James P. Gilreath ${ }^{1}$ \\ Gulf Coast Research and Education Center, University of Florida, Bradenton, \\ FL 34203
}

Carlene A. Chase and Salvadore J. Locascio

Horticultural Sciences Department, University of Florida, Gainesville, FL 32611-0690

Additional index words. Cucumis sativus, simulated drift, herbicide injury, flower abscission

\begin{abstract}
Cucumber (Cucumis sativus $\mathbf{L}$.) growth and yield in response to application of sublethal rates of 2,4-D at several developmental stages were evaluated in field studies during two seasons. In Expt. 1, prebloom applications of 2,4-D amine reduced plant vigor and increased foliar epinasty as rates increased from 0 to $112 \mathrm{~g} \cdot \mathrm{ha}^{-1}$. Early and total fruit yields also declined linearly as 2,4-D rates increased; $112 \mathrm{~g} \cdot \mathbf{h a}^{-1} \mathbf{2 , 4 - D}$ reduced early yield by $25 \%$ and total yield by $20 \%$. In Expt. 2, plant vigor declined with increasing rates of 2,4-D applied at all four stages of development from first true leaf to early fruit enlargement; however, response at stage 1 differed with time after application. Epinasty increased with 2,4-D rate when applied at all developmental stages; however the severity of the response varied with time after application for stages 1,2 , and 3 , but not for stage 4. Averaged over all developmental stages, vine length, fresh weight, and yield decreased linearly as rates increased. Early and total yields with $112 \mathrm{~g} \cdot \mathrm{ha}^{-1}$ were $22 \%$ and $19 \%$ lower than those of nontreated plants, respectively. Growth inhibition and yield decline, pooled across 2,4-D rates, were greater when exposure occurred at the earlier stages of development. Chemical name used: (2,4-dichlorophenoxy)acetic acid (2,4-D).
\end{abstract}

Drift of auxinic herbicides, such as 2,4-D, can cause considerable damage to nontarget crops. Exposure to 2,4-D stimulates ethylene formation, with higher production rates in sensitive plant species than in tolerant ones (Abeles, 1968; Tittle, 1990). The phytotoxicity of auxinic herbicides has been attributed to the accumulation of cyanide as a coproduct of ethylene synthesis (Tittle, 1990). Tomato (Lycopersicon esculentum Mill.) and pepper (Capsicum annuum $\mathrm{L}$.), which comprise $45 \%$ of the total vegetable production value in Florida (Witzig and Pugh, 2000), are sensitive to sublethal exposures of $11.2 \mathrm{~g} \cdot \mathrm{ha}^{-1}$ 2,4-D, especially during flowering (Gilreath et al., unpublished data). Flower numbers were lower in plants treated with 2,4-D than in nontreated plants as a result of accelerated senescence and abscission. A corresponding reduction in fruit numbercould account for lower fruit yields. Although cucumber is less important economically in Florida than are tomato and pepper (Witzig and Pugh, 2000), it is an important vegetable crop in Florida, other southeastern states, and many other parts of the United States.

Cucumber may be more tolerant of auxinic herbicide drift than are tomato and pepper.

Received for publication 13 Apr. 2000. Accepted for publication 16 Aug. 2000. Florida Agricultural Experiment Station Journal Series No. R-07747. The cost of publishing this paper was defrayed in part by the payment of page charges. Under postal regulations, this paper therefore must be hereby marked advertisement solely to indicate this fact.

${ }^{1}$ To whom requests for reprints should be addressed. E-mail address: DrGilreath@aol.com
Schroeder (1998) found that cucumber yield was unaffected by 2,4-D amine applications from 0.9 to $28 \mathrm{~g} \cdot \mathrm{ha}^{-1}$ at the initiation of vining; however, slight epinasty was noted with the highest rate. Hemphill and Montgomery (1981) observed mild epinasty with 2.1 to $20.8 \mathrm{~g} \cdot \mathrm{ha}^{-1}$ 2,4-D applied to cucumber at first bloom. Yields were reduced by $35 \%$ and $72 \%$ with 104 and $208 \mathrm{~g} \cdot \mathrm{ha}^{-1}$ 2,4-D, respectively, while rates of $\leq 20.8 \mathrm{~g} \cdot \mathrm{ha}^{-1}$ did not affect yield. In a second experiment, 2,4-D was applied after several fruit had set and were almost mature. Fruit shape was distorted and yield was reduced with $110 \mathrm{~g} \cdot \mathrm{ha}^{-1}$ with the lower rate of $11 \mathrm{~g} \cdot \mathrm{ha}^{-1} 2,4-\mathrm{D}$.

The objectives of our studies were to evaluate the effects of sublethal 2,4-D rates applied at various stages of development on the growth and yield of cucumber. We utilized a wider range of concentrations than was used by Schroeder (1998) and, unlike previous studies, compared the effects of exposure at several stages of development within an experiment.

\section{Materials and Methods}

Two experiments were conducted at the Gulf Coast Research and Education Center in Bradenton, Fla., on a subsurface-irrigated EauGallie fine sand (sandy, siliceous, hyperthermic, Alfic Haplaquod) soil. In both experiments, the experimental design used was a randomized complete block with six replications, row width was $1.4 \mathrm{~m}$, a guard row or ditch of equal width was interspersed between treated rows, and sprays were applied in a volume of $234 \mathrm{~L} \cdot \mathrm{ha}^{-1}$ with a $\mathrm{CO}_{2}$ backpack sprayer equipped with a single 11005 flat-fan nozzle tip.

Expt. 1. 'Marketmore 76' cucumber was direct-seeded at a rate of five seeds per hill at a spacing of $0.3 \mathrm{~m}$ on 11 Sept. 1987. Plants were thinned to 15 plants per plot. Plots were $4.6 \mathrm{~m}$ long and were separated by a $2.3-\mathrm{m}$ alley at each end. On 6 Oct., when vines were 40 to $50 \mathrm{~cm}$ long with no flowers, 2,4-D amine was applied using $90 \mathrm{kPa}$ pressure at $0,1.12,11.2$, and $112 \mathrm{~g} \cdot \mathrm{ha}^{-1}$ a.i. Plants were rated for vigor and epinasty on a scale from 0 to 10 at 1,10 , and $24 \mathrm{~d}$ after treatment. The highest vigor rating was 10 and a rating of 0 was used for dead plants. Symptoms of phytotoxicity included leaf cupping, leaf distortion, and twisting of stems. Ratings of 7 to 10 indicated severe epinasty, 4 to 6 moderate, 1 to 3 mild, and 0 no response. Fruit were harvested 10 times between 26 Oct. and 17 Nov. Misshapen fruit, such as bottle-neck and curved fruit, were culled and the yields of marketable fruits from all harvests were combined to derive total yield. Early yield in both experiments consisted of the sum of the yields of marketable fruits from the first four harvests.

Expt. 2. In the second experiment 'Poinsett 76' cucumber was direct-seeded on 11 Mar. 1988 to give 18 plants per single-row plot spaced $0.3-\mathrm{m}$ apart. Plot length was $5.5 \mathrm{~m}$; but, only a $3.0-\mathrm{m}$ length of the row was harvested. A 1.8-m alley at each end separated the plots. Rates of $0,0.11,1.12,11.2$, and $112 \mathrm{~g} \cdot \mathrm{ha}^{-1}$ 2,4-D amine were applied at four stages of plant development on 29 Mar., 15 Apr., 21 Apr., and 27 Apr. At stage 1, the first true leaf was fully expanded; at stage 2 , vines were 20 to $36 \mathrm{~cm}$ long with almost no flowers; at stage 3 , vines were $\approx 70 \mathrm{~cm}$ long with one to three blooms and an occasional, very small fruit; and at stage 4 , vines were $\approx 150 \mathrm{~cm}$ long with one fruit $\leq 15 \mathrm{~cm}$ long, a few smaller fruits, and many flowers. Treatments at stages 1 and 2 were applied at $76 \mathrm{kPa}$. At stages 3 and 4, each side of the bed was sprayed in a separate pass to ensure coverage, and spray pressure was increased to $90 \mathrm{kPa}$. Plant vigor, epinasty, early yield, and total yield were assessed as described for Expt. 1. Fruits were harvested seven times from 2 May to 25 May. After 2,4D applications at stages 1,2, and 3, one plant per treatment in each plot was sampled each week for 4 weeks to assess vine length and fresh weight.

Statistical analysis. Data were analyzed using the general linear models procedure of SAS (SAS Institute, 1988). Orthogonal polynomials were employed to examine the nature of the response to herbicide rate and time of evaluation. Regression curves were fitted to the means for early and total yields. In evaluating the main effect of stage of development, means were compared using Duncan's multiple range test or pairwise comparisons of least-squared means were performed (SAS Institute, 1988).

\section{Results and Discussion}

Expt. 1. Within $1 \mathrm{~d}$ of application of 11.2 and $112 \mathrm{~g} \cdot \mathrm{ha}^{-1}$ 2,4-D, plant vigor had de- 
creased and epinasty had increased (Table 1). Whereas improvement in plant vigor over time was observed with $11.2 \mathrm{~g} \cdot \mathrm{ha}^{-1}$ 2,4-D, vigor was only 6.4 at $1 \mathrm{~d}$ after treatment (DAT) with $112 \mathrm{~g} \cdot \mathrm{ha}^{-1}$ and did not change over the next $24 \mathrm{~d}$. Mild epinasty occurred $1 \mathrm{~d}$ after application of $11.2 \mathrm{~g} \cdot \mathrm{ha}^{-1}$ 2,4-D, but plants recovered rapidly over the next $24 \mathrm{~d}$. Conversely, epinasty in plants treated with $112 \mathrm{~g} \cdot \mathrm{ha}^{-1}$ was severe at 1 DAT and moderate epinasty was still apparent 24 DAT. Early yields declined linearly by $26 \%$ (from 16.1 to $11.9 \mathrm{t} \cdot \mathrm{ha}^{-1}$ ) as 2,4-D rates increased from 0 to $112 \mathrm{~g} \cdot \mathrm{ha}^{-1}$ (yield $=-37.6($ rate $)+16.1, r^{2}>$ 0.99 , data not shown). Total yields also declined linearly from 39.7 to $31.9 \mathrm{t} \cdot \mathrm{ha}^{-1}$, a $20 \%$ decrease [yield $=-69.4($ rate $)+39.7, r^{2}>0.99$ ] (data not shown).

Expt. 2. In the second experiment, the effect of 2,4-D rate on vigor of plants treated at stage 1 , differed with time of evaluation $(P$ $\leq 0.05)$. Reduction in vigor was linear with increasing 2,4-D rates 1 week after treatment (WAT) at stage 1 (Table 2). At three subse-

Table 1. Plant vigor and epinasty of cucumber plants as affected by 2,4-D rate and time of evaluation after application (Expt. 1). ${ }^{\mathrm{p}}$

\begin{tabular}{lccccccccc}
\hline \hline \multirow{2}{*}{$\begin{array}{l}\text { Rate } \\
\left(\mathrm{g} \cdot \mathrm{ha}^{-1}\right)\end{array}$} & DAT $^{\mathrm{y}}:$ & 1 & 10 & 24 & $\mathrm{Sig}$ & & & \multicolumn{4}{c}{ Epinasty } \\
\hline 0 & 9.9 & 9.8 & 9.8 & $\mathrm{NS}$ & & 0 & 0 & 24 & Sig. \\
1.12 & 9.9 & 9.5 & 9.6 & $\mathrm{NS}$ & & 0 & 0.1 & 0 & $\mathrm{NS}$ \\
11.2 & 8.4 & 9.0 & 9.4 & $\mathrm{~L}^{*}$ & & 3.1 & 0.8 & 0.3 & $\mathrm{~N}$ \\
112 & 6.4 & 6.6 & 6.3 & $\mathrm{NS}$ & & 8.6 & 4.8 & 4.7 & $\mathrm{Q}^{* *}$ \\
Significance & $\mathrm{Q}^{* *}$ & $\mathrm{~L}^{* *}$ & $\mathrm{~L}^{* *}$ & & & $\mathrm{Q}^{* *}$ & $\mathrm{~L}^{* *}$ & $\mathrm{~L}^{* *}$ &
\end{tabular}

${ }^{2}$ Vigor was rated on a scale from 0 to 10 , with 10 being the highest vigor and 0 indicating death. The most severe epinasty was assigned a rating of 10 and 0 indicated there was none. yDays after treatment.

Ns, ${ }^{* * * *}$ Nonsignificant and significant at $P \leq 0.05$ and $P \leq 0.01$, respectively, for linear (L) and quadratic $(\mathrm{Q})$ effects.

Table 2. Effect of 2,4-D rate, developmental stage, and time of evaluation on cucumber plant vigor (Expt. 2). ${ }^{\mathrm{z}}$

\begin{tabular}{|c|c|c|c|c|c|c|c|c|c|}
\hline \multirow{2}{*}{$\begin{array}{l}\text { Rate } \\
\left(\mathrm{g} \cdot \mathrm{ha}^{-1}\right)\end{array}$} & \multirow[b]{2}{*}{ WAT $^{\mathrm{x}}$ : } & \multicolumn{5}{|c|}{ Stage 1} & \multirow[b]{2}{*}{ Stage $2^{y}$} & \multirow[b]{2}{*}{ Stage $3^{y}$} & \multirow[b]{2}{*}{ Stage $4^{y}$} \\
\hline & & 1 & 2 & 3 & 4 & Sig. & & & \\
\hline$\overline{0}$ & & 9.6 & 9.6 & 9.3 & 9.8 & NS & 9.6 & 9.7 & 9.8 \\
\hline 0.11 & & 9.6 & 9.0 & 9.3 & 9.7 & NS & 8.5 & 8.9 & 9.5 \\
\hline 1.12 & & 8.6 & 8.5 & 8.7 & 8.5 & NS & 9.1 & 9.2 & 9.5 \\
\hline 11.2 & & 8.4 & 7.7 & 7.4 & 8.0 & NS & 8.7 & 8.6 & 9.2 \\
\hline 112 & & 5.0 & 3.5 & 2.2 & 4.0 & $\mathrm{Q}^{* *}$ & 6.9 & 6.8 & 8.6 \\
\hline Significance & & $\mathrm{L}^{* *}$ & $\mathrm{Q}^{*}$ & $\mathrm{Q}^{* *}$ & $\mathrm{Q}^{* *}$ & & $\mathrm{~L}^{* *}$ & $\mathrm{Q}^{* *}$ & $\mathrm{~L}^{* *}$ \\
\hline
\end{tabular}

${ }^{2}$ Plant vigor was rated on a scale from 0 to 10 , with 10 being the highest vigor and 0 indicating death. y Data averaged over time of evaluation.

${ }^{x}$ Weeks after treatment.

Ns, *** Nonsignificant and significant at $P \leq 0.05$ and $P \leq 0.01$, respectively, for linear (L) and quadratic $(\mathrm{Q})$ effects. exhibited no symptoms of epinasty; however, following application of 0.11 and $1.12 \mathrm{~g} \cdot \mathrm{ha}^{-1}$ 2,4-D, epinasty was very mild for 3 WAT and had decreased to its lowest levels by 4 WAT. Epinasty was mild 1 WAT with $11.2 \mathrm{~g} \cdot \mathrm{ha}^{-1}$ 2,4-D, increased to a moderate level by 2 WAT, then declined to its lowest level at 4 WAT. Three weeks following application of $112 \mathrm{~g} \cdot \mathrm{ha}^{-1} 2,4-\mathrm{D}$, plants exhibited severe epinasty, which had declined to a moderate level by 4 WAT.

Increasing rates of 2,4-D applied at stage 2 also increased epinasty. The increase was quadratic during the first 3 WAT and linear at 4 WAT. Epinasty was mild with $0.11,1.12$, and $11.2 \mathrm{~g} \cdot \mathrm{ha}^{-1}$ and declined to lowest levels at 4 WAT. Treatment with $112 \mathrm{~g} \cdot \mathrm{ha}^{-1}$ 2,4-D, induced moderate epinasty 1 WAT; this declined with time to a mild level at 4 WAT. Response was quadratic as the rate of 2,4-D applied at stage 3 increased. Epinasty was mild at rates of 0.11 to $11.2 \mathrm{~g} \cdot \mathrm{ha}^{-1}$, and a timedependent decrease occurred only with the $1.12 \mathrm{~g} \cdot \mathrm{ha}^{-1}$ rate. Epinasty was moderate with $112 \mathrm{~g} \cdot \mathrm{ha}^{-1}$ 2,4-D, declining from 5.6 at $1 \mathrm{WAT}$ to 3.5 at 4 WAT. For 2,4-D applications at stage 4, data were pooled over time of evaluation. Epinasty increased quadratically from zero in nontreated plants to 2.9 in plants treated with $112 \mathrm{~g} \cdot \mathrm{ha}^{-1}$. Averaged over 2,4-D rate, epinasty was mild and no change in response occurred with time of evaluation (data not shown).

Vine length and fresh weight, averaged over developmental stage, decreased linearly with increasing rates of 2,4-D (Table 4). Both were greater when exposure to 2,4-D occurred later in plant development. Vine length was three times as long and fresh weight was five times as great following 2,4-D applications at stage 3 than following applications at stage 1 .

Interaction between $2,4-\mathrm{D}$ rate and stage of development at application did not affect yield, so data were pooled over developmental stage. Early and total yields decreased by $22 \%$ and $19 \%$, respectively, as 2,4-D rate increased to $112 \mathrm{~g} \cdot \mathrm{ha}^{-1}$ (Table 4). Decline was linear for both early and total yield (early yield $=-105.8$ (rate $)+55.8, r^{2}=0.88$; total yield $=-307.2($ rate $\left.)+168.4, r^{2}=0.95\right)$. Averaged over 2,4-D rate, early yield was less sensitive to 2,4-D as exposure to the herbicide was delayed, so that early yield was lowest when 2,4-D was applied at stage 1 and highest when exposure occurred at stage 4 . Statistically similar early yields were obtained with

Table 3. Effect of 2,4-D rate, developmental stage, and time of evaluation on foliar epinasty in cucumber (Expt. 2).

\begin{tabular}{|c|c|c|c|c|c|c|c|c|c|c|c|c|c|c|c|c|}
\hline \multirow{2}{*}{$\begin{array}{l}\text { Rate } \\
\left(\mathrm{g} \cdot \mathrm{ha}^{-1}\right)\end{array}$} & \multirow[b]{2}{*}{ WAT:y } & \multicolumn{5}{|c|}{ Stage 1} & \multicolumn{5}{|c|}{ Stage 2} & \multicolumn{4}{|c|}{ Stage 3} & \multirow[b]{2}{*}{ Stage 4} \\
\hline & & 1 & 2 & 3 & 4 & Sig. & 1 & 2 & 3 & 4 & Sig. & 1 & 2 & 4 & Sig. & \\
\hline 0 & & 0 & 0 & 0 & 0 & NS & 0.1 & 0 & 0 & 0 & NS & 0 & 0 & 0 & NS & 0 \\
\hline 0.11 & & 0.4 & 0.8 & 0.3 & 0 & $\mathrm{Q}^{* *}$ & 0.9 & 1.4 & 0.4 & 0 & $\mathrm{~L}^{*}$ & 0.6 & 0.4 & 0.4 & NS & 0.2 \\
\hline 1.12 & & 1.3 & 1.8 & 1.1 & 0.7 & $\mathrm{Q}^{*}$ & 1.6 & 2.1 & 0.9 & 0.2 & $\mathrm{Q}^{*}$ & 2.2 & 0.8 & 0.9 & $\mathrm{~L}^{* *}$ & 0.7 \\
\hline 11.2 & & 2.3 & 4.3 & 2.1 & 1.4 & $\mathrm{Q}^{* *}$ & 2.8 & 2.1 & 1.6 & 0.8 & $\mathrm{~L}^{* *}$ & 2.4 & 2.0 & 1.6 & NS & 1.5 \\
\hline 112 & & 7.8 & 8.0 & 8.0 & 3.7 & $\mathrm{Q}^{* *}$ & 6.8 & 4.7 & 4.1 & 2.9 & $\mathrm{~L}^{* *}$ & 5.6 & 4.8 & 3.5 & $\mathrm{~L}^{* *}$ & 2.9 \\
\hline Significance & & $\mathrm{Q}^{* *}$ & $\mathrm{Q}^{* *}$ & $\mathrm{Q}^{* *}$ & $\mathrm{Q}^{* *}$ & & $\mathrm{Q}^{* *}$ & $\mathrm{Q}^{* *}$ & $\mathrm{Q}^{* *}$ & $\mathrm{~L}^{* *}$ & & $\mathrm{Q}^{* *}$ & $\mathrm{Q}^{* *}$ & $\mathrm{Q}^{* *}$ & & $\mathrm{Q}^{* *}$ \\
\hline
\end{tabular}

${ }^{2}$ Epinasty was rated from 0 (none) to 10 (most severe).

'Weeks after treatment.

${ }^{x}$ Data averaged over time of evaluation.

ss, ,***Nonsignificant and significant at $P \leq 0.05$ and $P \leq 0.01$, respectively for linear (L) and quadratic (Q) effects. 
Table 4. Main effects of 2,4-D rate and stage of development on cucumber vine length, fresh weight, and yield (Expt. 2).

\begin{tabular}{|c|c|c|c|c|}
\hline \multirow[b]{2}{*}{ Factor } & \multirow{2}{*}{$\begin{array}{c}\text { Length } \\
(\mathrm{cm})\end{array}$} & \multirow{2}{*}{$\begin{array}{c}\text { Fresh wt } \\
(\mathrm{g})\end{array}$} & \multicolumn{2}{|c|}{ Yield $\left(\mathrm{t} \cdot \mathrm{ha}^{-1}\right)$} \\
\hline & & & Early & Total \\
\hline \multicolumn{5}{|l|}{ Rate $\left(\mathrm{g} \cdot \mathrm{ha}^{-1}\right)^{\mathrm{z}}$} \\
\hline 0 & 135 & 1013 & 55.9 & 164.9 \\
\hline 0.11 & 134 & 1064 & 57.1 & 168.4 \\
\hline 1.12 & 136 & 1059 & 53.0 & 172.9 \\
\hline 11.2 & 133 & 1042 & 55.8 & 163.5 \\
\hline 112 & 110 & 832 & 43.8 & 134.1 \\
\hline Significance & $\mathrm{L}^{* *}$ & $\mathrm{~L}^{* *}$ & $\mathrm{~L}^{* *}$ & $\mathrm{~L}^{* *}$ \\
\hline \multicolumn{5}{|l|}{ Stage ${ }^{y}$} \\
\hline 1 & $60.1 c^{x}$ & $312 c^{x}$ & $44.2 c^{w}$ & $147.1 \mathrm{~b}^{\mathrm{w}}$ \\
\hline 2 & $148.5 \mathrm{~b}$ & $1126 \mathrm{~b}$ & $50.9 \mathrm{~b}$ & $150.3 \mathrm{~b}$ \\
\hline 3 & $179.8 \mathrm{a}$ & $1569 a$ & $53.9 \mathrm{~b}$ & $152.2 \mathrm{~b}$ \\
\hline 4 & --- & --- & $63.6 \mathrm{a}$ & $193.5 \mathrm{a}$ \\
\hline \multicolumn{5}{|c|}{${ }^{\mathrm{z}}$ Data averaged over stage of development. } \\
\hline
\end{tabular}

applications at stages 2 and 3 . The highest total yield occurred when 2,4-D was applied at stage 4. Applications of 2,4-D at stages 1, 2, and 3 resulted in similar total yields.

Cucumber appears to be relatively tolerant of sublethal rates of 2,4-D. In the present study, $112 \mathrm{~g} \cdot \mathrm{ha}^{-1}$ 2,4-D reduced yield by only $20 \%$. Schroeder (1998) also reported evidence of cucumber tolerance to low rates of 2,4-D. Although epinasty was apparent with the highest rate used $\left(28 \mathrm{~g} \cdot \mathrm{ha}^{-1}\right)$, yield was unaffected. Similarly, Hemphill and Montgomery (1981) reported no effect on cucumber yield with rates of 2.1 and $20.8 \mathrm{~g} \cdot \mathrm{ha}^{-1}$; however, with 104 and $208 \mathrm{~g} \cdot \mathrm{ha}^{-1}$, yields were reduced by $35 \%$ and $72 \%$, respectively. In a second season, plants were more sensitive, and 11 $\mathrm{g} \cdot \mathrm{ha}^{-1}$ 2,4-D reduced yield $25 \%$ (Hemphill and Montgomery, 1981). The difference in sensitivity may have been due to cultivar, since 'Victory' was used the first year and 'Pacer' the second. Although yields with 'Poinsett 76' in our study were higher than with 'Marketmore 76', the percentage of de- crease in yield was similar and may indicate similar levels of tolerance to 2,4-D. Rapid metabolism of 2,4-D has been demonstrated in cucumber (Chkanikov et al., 1977; Klems et al., 1998) and may account for its tolerance of low rates of 2,4-D.

Flower abscission has been observed in response to sublethal rates of auxinic herbicides (Gilreath et al., unpublished; Orsenigo, 1964, Robbins and Taylor, 1957) and the resulting reduction in fruit set may account for reduced yields. Abscission continued all season when tomato plants were exposed to 2,4-D at first bloom (Robbins and Taylor, 1957). Although the effect of auxinic herbicides on cucumber flower number has not been reported previously, evidence of reduced fruit set is available. When cucumber plants of the sensitive cultivar 'Pacer' were sprayed with $11 \mathrm{~g} \cdot \mathrm{ha}^{-1}$ 2,4-D after some fruit had already set, the first harvest was unaffected. Although yield at the second harvest was reduced, recovery was apparent by the third harvest (Hemphill and Montgomery, 1981).
Application of 11.2 and $112 \mathrm{~g} \cdot \mathrm{ha}^{-1}$ 2,4-D to cucumber resulted in inhibition of vigor and induced foliar epinasty. Growth, measured as vine length and fresh weight, was inhibited to a greater extent when 2,4-D exposure occurred at early stages of development. However, yields were less affected by 2,4-D; 112 $\mathrm{g} \cdot \mathrm{ha}^{-1} 2,4-\mathrm{D}$ reduced yield only $20 \%$. Early yields were less inhibited when exposure to 2,4-D occurred later in the crop's development.

\section{Literature Cited}

Abeles, F.B. 1968. Herbicide-induced ethylene production: Role of the gas in sublethal doses of 2,4-D. Weed Sci. 16:498-500.

Chkanikov, D.I., N.N. Pavlova, A.M. Makeev, T.A. Nazrova, and A. Yu. Makoveichuk. 1977. Paths of detoxification and immobilization of 2,4-D in cucumber plants. Soviet Plant Physiol. 24:457463.

Hemphill, D.D. and M.L. Montgomery. 1981. Response of vegetable crops to sublethal application of 2,4-D. Weed Sci. 29:632-635.

Klems, M., M. Truksa, I. Machácková, J. Eder, and S. Procházka. 1998. Uptake, transport and metabolism of ${ }^{14} \mathrm{C}$-2,4-dichlorophenoxyacetic acid $\left({ }^{14} \mathrm{C}-2,4-\mathrm{D}\right)$ in cucumber (Cucumis sativus L.) explants. Plant Growth Regulat. 26:195-202.

Orsenigo, J.R. 1964. Some vegetable responses to chlorophenoxy herbicide exposure. Proc. Fla. State Hort. Soc. 77:230-232.

Robbins, W.A. and W.S. Taylor. 1957. Injury to canning tomatoes caused by 2,4-D. Proc. Amer. Soc. Hort. Sci. 70:373-378.

SAS Institute. 1988. SAS/STAT user's guide, release 6.03 ed. SAS Inst., Cary, N.C.

Schroeder, J. 1998. Cucumber (Cucumis sativus) response to selected foliar- and soil-applied sulfonylurea herbicides. Weed Technol. 12:595601.

Tittle, F.L., J.S. Goudey, and M.S. Spencer. 1990 Effect of 2,4-dichlorophenoxyacetic acid on endogenous cyanide, -cyanoalanine synthase activity, and ethylene evolution in seedlings of soybean and barley. Plant Physiol. 94:11431148.

Witzig, J.D and N.L. Pugh. 2000. Florida agricultural statistics vegetable summary 1998-99. Florida Agr. Stat. Serv., Orlando. 